\begin{tabular}{c} 
Volume and Issues Obtainable at Center for Sustainability Research and Consultancy \\
Journal of Accounting and Finance in Emerging Economies \\
ISSN: 2518-0318 ISSN (E) 2518-8488 \\
Volume 6: Issue 2 June 2020 \\
JSRᄃ \\
Journal homepage: www.publishing.globalcsrc.org/jafee \\
\hline
\end{tabular}

\title{
Shariah Governance Characteristics and Risk-Taking of Local and Foreign Islamic Banks in Malaysia: A Conceptual Model
}

\author{
${ }^{1}$ Salina Rasli, ${ }^{2}$ Aza Azlina Md Kassim, ${ }^{3}$ Abul Bashar Bhuiyan \\ ${ }^{1} \mathrm{PhD}$ Scholar, Faculty of Business and Accountancy, Universiti Selangor, Shah Alam, Malaysia, \\ rsalina@unisel.edu.my \\ ${ }^{2}$ Lecturer, Faculty of Business and Accountancy, Universiti Selangor, Shah Alam, Malaysia, \\ aza_azlina@unisel.edu.my \\ ${ }^{3}$ Lecturer, Faculty of Business and Accountancy, Universiti Selangor, Shah Alam, Malaysia, \\ bashar@unisel.edu.my
}

\begin{tabular}{l}
\hline ARTICLE DETAILS \\
\hline History \\
Revised format: May 2020 \\
Available Online: June \\
2020 \\
\hline
\end{tabular}

Keywords

Shariah Governance,

Shariah Board,

Risk-Taking,

Islamic Banks

JEL Classification

M40, M41

\begin{abstract}
Purpose: In Malaysia, since the global financial crisis in 2007 and 2008, the low level of stability, excessive risk-taking and weak governance structure in the dual banking system has become essential for deliberation. The purpose of this manuscript is to develop a conceptual model on the effect of Shariah governance characteristics on risk-taking between local and foreign of Islamic banks in Malaysia.

Design/Methodology/Approach: Based on prior review of indicators and findings, this manuscript proposes a conceptual model of effective Shariah governance characteristics and its effect on risk-taking of Islamic banks. A self-develop of Shariah board index (SB-Index) based on SB size, education background, membership with IFSB and attendance in meeting. Insolvency risk, credit risk and liquidity risk are the proxy used for risk-taking measurement. The theory of stewardship and resource dependency theory are used as examples of the theories of corporate governance to support the conceptual framework suggested.

Findings: The Islamic banks in Malaysia are assumed to have effective Shariah governance and there will be low impact on risktaking.

Implications/Originality/Value: The regulators of Islamic banks must prepare for the need to improve the current standards for corporate governance in Malaysia.
\end{abstract}

\section{OPEN ACCESS}

(C) 2020 The authors, under a Creative Commons Attribution-

NonCommercial 4.0

Corresponding author's email address: rsalina@unisel.edu.my

Recommended citation: Rasli, S., Md Kassim, A.A. and Bashar, A.B. (2020). Shariah Governance Characteristics and Risk-Taking of Local and Foreign Islamic Banks in Malaysia: A Conceptual Model. Journal of Accounting and Finance in Emerging Economies, 4 (2), 441-451 


\section{Introduction}

In banking business, either the conventional or Islamic banks need to make managerial decisions involving risk-taking. Corporate risk-taking activities can foster firms' long-term growth (Faccio, Marchica, \& Mura, 2011), but excessive risk-taking behaviour can be exacerbate financial stability and harmful to firms as well as economic growth of the country. The excessive risk taking behaviour in the banking industry is mainly contributed from re-occurrence of financial crisis such as the Asian financial crisis in 1998 (Muchhala, 2007) and the Global Financial Crisis in 2008 (Paligorova, 2011). A Turkey Islamic bank namely Ihlas Finans House, collapsed in 2000/2001 (Ali, 2007) and Bank Islam Malaysia Berhad in Malaysia suffered with great financial loss in 2005. Reasons being, they have poor risk management and excessive risk-taking (Ramly, Nurusysyifa, \& Mohamad, 2018; Fakhrunnas \& Ramly, 2017). Due to this, the comprehensive monitoring and controlling of financial stability and soundness of Islamic banks in Malaysia is very important.

Hence, the Islamic finance environment seems to be dominated by the conventional financial sector, with similar risks from Islamic banks and conventional banks. As for example, Khan and Ahmad (2001) remarked the inherent risk such as the credit risk of the Islamic banks which adopted interest rate as much as KLIBOR among the Malaysian Islamic banks. This situation encourages the Islamic banks giving too many loans to less creditworthy borrowers (Mokni, Rajhi, \& Rachdi, 2016). In addition, liquidity risk, which is another type of risk owned by the Islamic banks, affects the capability of Islamic banks to fulfill their liability. Furthermore, Islamic banks are fully exposed to the variety of risk types because they are to comply with the Shariah rule. It is imperative to avoid putting in place the core concepts of riba, gharar and maysir in the products and services provided (Chapra \& Ahmed, 2002).

Replicated from poor conventional banks, the corporate governance could lose confidence of stakeholders, and increases the liquidity crisis as well as systemic risk of the country as a whole (Htay \& Rashid, 2011). Therefore, the effectiveness of internal corporate governance mechanism would assume to understand on the risk management by allocating the right people in the right location to gain high return (Fakhrunnas \& Ramly, 2017). Islamic banks has "additional layer" of corporate governance structure known as Shariah Governance (SG) referred to as a system of controlling, guiding and directing the Shariah Board (SB). The existence of the structures is to ensure the compatibility with the Shariah laws. The challenges of the governance need to be addressed as all the stakeholders including investors, regulators and the public placed their interest on the financial stability of Islamic banks system (Grassa \& Matoussi, 2014).

Malaysian dual banking system has been practiced with co-exist of Islamic banks and the conventional banks. As conventional banks demonstrate virtuous standing, Islamic banks are also growing tremendously due to the market acceptance and the recognition from majority of Malaysian population about religious principles in Islamic banking system (Mirza, Rahat, \& Reddy, 2016). While these dual banking system encourage competiveness, Islamic banks need to create sophisticated Islamic financial products in order to gain more popularity and become customers' choice in Islamic banking industry (Muda, Shaharuddin, \& Embaya, 2013). Furthermore, the Central Bank of Malaysia (BNM) has taken an incentive by introducing the entry of the foreign Islamic banks with the liberalization of the Islamic banking industry since the mid-1990s. The consequence of having foreign banks would help rising the capital contribution to the economy as well as the competitiveness of expertise and culture in the industry (Ibrahim, Xiang, Nik Azman, \& Zulkafli, 2018).

There are still very few studies exploring the influence of Shariah governance on Islamic banks risktaking (Alman, 2012; Almutairi \& Qutainnah, 2017; Safiullah \& Shamsuddin, 2018). Mollah, Hassan, Al Farooque, and Mobarek (2017) suggested that, the Islamic banks which offered product complexities and transactions mechanisms, the governance structure should permit them to take risks at higher level in order to achieve better performance as to be found in the structure of Shariah governance and the conventional board (Bhatti \& Bhatti, 2010). Indeed, the formulation of systematic principles of 
governance is also deliberated to minimize the use of severe and risky financial products. This manuscript further explore on the corporate governance theories such as the Stewardship Theory (STD) and Resource Dependence Theory (RDT) to describe the impact of Shariah board characteristics on Islamic banks risk-taking as discussed by the prior literature (see, for examples; Nomran, Haron, \& Hassan, 2018; Hakimi, Rachdi, Mokni, \& Hssini, 2015).

\section{Bank Governance Theories}

In prior researches, bank governance theories are commonly discussed consisting of agency theory, stewardship theory, resource dependency theory, and stakeholder theory. This manuscript focuses solely on stewardship theory and resource dependency theory applicable to Islamic banking studies (Bilal Saeed \& Kashif Saeed, 2018; Nomran, Haron \& Hassan, 2018; Nomran, Haron, \& Hassan, 2017). The stewardship philosophy sees managers as good stewards of the business organization who work diligently to achieve a high level of corporate profit and returns for shareholders (Donaldson \& Davis, 1991; Abdullah \& Valentine, 2009; Cornforth \& Chambers, 2010). Meanwhile, the resourcedependency theory classifies corporate governance structures as the resources of the organization and implies that the resources of the business are the key determinants of its performance (Hillman, Cannella, \& Paetzold, 2000; Abdullah \& Valentine, 2009; Bernadette Josephine \& Corina, 2015).

\section{Related Literature and Hypothesis Development}

\section{1 Islamic Banks and Risk-Taking}

Due to the complexity of modern financial systems as well as global regulatory patterns, the definition of risk taking is difficult to define and even more difficult to measure. In addition, risk-taking in Islamic banks is more important and difficult in comparison with traditional banks due to the heterogeneity of contractual characteristics (Mudharabah and Musyarakah), general legal requirement (Basah et al., 2018) and clients ' religious beliefs which can promote greater loyalty and discourage default (Abedifar, Ebrahim, Molyneux, \& Tarazi, 2015). Safiullah and Shamsuddin (2018) stressed that Islamic banks are exposed to a higher liquidity risk, lower credit risk, lower insolvency risk, but face similar operating risk compared to conventional banks. In this manuscript, the risk-taking is further addressed on the risk of insolvency, credit risk and liquidity risk.

\subsubsection{Islamic Banks and Insolvency Risk}

The Z-score ratio is widely used to measure banking soundness and financial stability (Čihák \& Hesse, 2010). Lindgren, Garcia, and Saal (1996) described bank soundness as the bank's ability to maintain hostile insolvency with bank efficiency, major changes in financial banking policy, liberalization of the financial sector and natural disaster. The Z-score stated by Laeven and Levine (2007) shows that the bank's valuation of standard deviations suggests a lower profitability of its assets (ROA) than predicted and before capital losses. A higher Z-score designates that the bank is very stable. Furthermore, insolvency is referred to when losses of banks is greater than the total capital. Therefore, if the bank suffered significant losses, the value of the assets will fall below the debts to the sum of depositors. This indicates a negative capital status and will expose to a significant problem of withdrawals.

Alharthi (2017) described the quoted Islamic banks as being more stable than the unquoted Islamic banks and the banks listed had lower capitals as well. Mokni, Rajhi and Rachdi (2016) empirically found that MENA Islamic banks are less stable than conventional banks, and that they also have determinants of risk-taking. Abedifar, Molyneux and Tarazi (2013), Chakroun and Gallali (2013), and Čihák and Hesse (2010) analysed the risk of insolvency using the Z-score measurement usually found that small conventional banks have high default risk compared to small Islamic banks. Čihák and Hesse (2010) considered conventional banks to be more robust than the largest Islamic banks, whereas Abedifar, Molyneux and Tarazi (2013) and Beck, Demirgüç-Kunt and Merrouche (2013) found no such discrepancy. 


\subsubsection{Islamic Banks and Credit Risk}

The earlier studies in measuring the credit risk, ratio of non-performing loans (NPL) has been commonly used in banking studies. The NPL is one of the bank loans that determine whether interest and principal payments have been overdue by 90 days or more. Credit risk refers to the probability that failed lender will pay the loan as outlined in the contract. Islamic banks may have a different credit risk profile due to the different funding methods compared to the conventional banks. Several factors could lead to the high credit risk for Islamic banks because of the moral hazard incentives for lenders to share losses with banks in its profit and loss sharing (PLS) (El-Hawary, Grais, \& Iqbal, 2007). Islamic banks may also be exposed to increased credit risk due to religious constraints on the use of conventional credit risk management instruments such as credit derivatives (Errico \& Farahbaksh, 1998).

Nevertheless, contract forms between borrowers and banks can minimize credit risk due to knowledge asymmetry, which increases adverse selection issues and fosters a better understanding of the creditworthiness of borrowers (Errico \& Farahbaksh, 1998). Islamic banks may also be less vulnerable to credit risk by inducing loyalty and preventing default because of borrowers' religious confidence in the Islamic banking system (Abedifar, Molyneux, \& Tarazi (2013); (Baele, Farooq, \& Ongena, 2014). Misman, Bhatti, Lou, Samsudin and Abd Rahman (2015) indicated that any deterioration in the value of lending causes banks to make higher provisions for losses, thereby raising the implied level of credit risk.

\subsubsection{Islamic Banks and Liquidity Risk}

Sulaim and Rashid (2018) defined liquidity risk as when banks incapability to acquire funding from short funds deposits in order to finance loans at a longer term. Furthermore, liquidity management ensures that there are sufficient cash balances for withdrawals and savings from customers, high assets quality and the ability to sustain all expenditures incurred (Olagunju, David \& Samuel, 2011). The trigger of liquidity risk of banks, however, are misclassified of assets and liabilities in financial reporting and broaden loans and credit to high-risk borrowers (Ayunku, 2017). Studies have demonstrated that liquidity risk management plays a significant role in Islamic banking. For instance, Safiullah and Shamsuddin (2018) used loan-to-deposit ratio as a proxy to measure liquidity risk to identify how banks in 28 countries use liquid deposits to fund illiquid loans between Islamic banks. They also described the high loan-to-deposit ratio, suggesting greater dependency on non-deposit funds to support lending growth and liquidity demand.

Ismal (2010) suggested that the stability of banking institutions would reduce the liquidity problems by maintaining a good relationship with relevant stakeholders. It would also successfully handle the liquidity demand and supply in line with the bank requirements. Therefore, the incompetence in managing the funds or sudden losses of liquidity during volatile economic condition is considered. The Central Bank of Malaysia (BNM), issued several guidelines relating to liquidity risk management (LRM) namely are: liquidity coverage ratio (BNM/RH/STD 029-9), liquidity framework of conventional financial institutions, liquidity framework of Islamic financial institutions (BNM/RH/GL/002-12), risk governance (BNM/RH/GL 013-5) and Basel III implementation for liquidity risk management bases.

\subsection{Shariah Governance in Malaysia}

Good and dynamic Shariah governance (SG) is very important to the growth of the Islamic banking and financial sector in Malaysia. This good Shariah governance has kept Islamic financial growth rapid (Hasan, 2010). The stakeholders' interest in good corporate governance will go beyond financial interests to social, religious or other principles. The operations of Islamic banks' (IB) are essentially based on the principle of profit and loss (risk-sharing) as opposed to interest-driven (riba) activities as in conventional banks (CBs) (Mollah \& Zaman 2015).

As a result, Bank Negara Malaysia (BNM) implemented the Shariah Governance Framework (SGF) for Islamic Financial Institutions in 2010, and further reinforced the latest implementation in 2013 of the Islamic Financial Services Act (IFSA) which makes clear provisions for Shariah governance, something 
that its predecessor, the Islamic Banking Act of 1993, cannot abide. In general, before SGF (2010) and IFSA (2013) were released, most IB voluntarily complies and follows the global standard and guidelines, issued by the Islamic Finance Institution (AAOIFI) accounting and auditing organization and the Islamic Financial Service Board (IFSB) (Ismail \& Hassan, 2016).

Shariah governance may be referred to as the mechanism of governing and guiding the Shariah Supervisory Board (SSB) in order to ensure compatibility with the Shariah laws (Grassa 2013). In Malaysia, the term Shariah Committee or Shariah Supervisory Board (SSB) was used interchangeably (Hasan, 2010). The creation of SSB was compelled by IFSA 2013 and SGF 2010. In general, the main function of SSB is to advise the board of directors on Shariah matters. It also has to ensure that any transaction made, follow the Shariah standards at all times, endorse and check relevant product and service records, as well as internal policies, manuals and marketing advertisements (Hasan 2010).

\subsubsection{Shariah Board Characteristics and Risk-Taking}

Hassan and Mollah (2014) agreed that the Shariah board (SB) acts as an independent control mechanism to prevent the board of directors and other governance agents from engaging in risk-taking practices, thereby preventing the IB board structure from taking undue risk during financial turmoil. The SB in the IB board structure, however, is morality and ethics-oriented rather than greed; therefore, IB boards alleviate shareholder benefits as they do to the detriment of taxpayers or perverse incentives or deposit insurance, with the IB board focusing on maintaining social justice. Therefore, during the financial turmoil, IB board will take fewer chances and hopefully IB will recover from the financial crisis.

The stronger the Shariah supervisory power of a larger SB is also likely to limit the aggressive financing and borrowing activities of a director, which may in effect reduce the risk of Islamic banks. Alman (2012) suggested that the decentralized shariah-compliant governance structure, supervisory efficiency and disciplining capacity of individual SB banks against risk-taking decreases in Islamic banks' loan portfolio. The SB plays a major role in maintaining good governance of Shariah. Shariah governance, namely Shariah committee attributes is affected by the bank profitability, indicating that the higher trust of Islamic banks with the Shariah committee members encourages them to be more transparent (Masruki, Hanefah \& Wahab, 2018). Every factor that drives towards the success of Islamic Financial Institutions (IFIs) has their own unique characteristics, and Shariah governance is no exception. Furthermore, this manuscript will concentrate on Shariah management structures of Islamic banks, which consists of the size, the level of education, IFSB membership and the frequency of scholars meetings.

\subsubsection{Shariah Board Size and Risk-Taking}

Since the Shariah Board's decision includes understanding Islamic law, modern banking and finance, and legal issues, having more SB members with different professional backgrounds will enable legal Shariah decision-making and greater compliance with Shariah principles and, as such, will influence risk levels in Islamic banks. In addition, it is easy for the management and board of directors to control the small size Shariah board whereas it is difficult for them to control a large size Shariah board. The minimum number of Shariah boards members is five (5) and there is no maximum number of members (BNM, 2013). A study conducted in Malaysia by Othman et al. (2013) shows that most of the Islamic Financial Institutions have 5 SB members. $75.3 \%$ of the respondents reported they had 5 members, $16.0 \%$ of the respondents had more than 5 members while only $8.6 \%$ of the respondents had few members with 5 . This is a very good indication as about $92.4 \%$ of the institutions have achieved the required numbers of the $\mathrm{SB}$ required numbers of the members.

The resource dependence theory also implies that larger boards possess a range of expertise and experience and are therefore able to offer higher quality guidance and advice to companies (Dalton, Daily, Johnson \& Ellstrand, 1999). The resource-dependence theory (RDT) suggested that a larger SB could also influence the boards' ability to improve credit quality, policies, and strategies ex-ante Shariah 
screening and minimize the moral hazard of managers by implementing less rigorous borrowers' business monitoring. Also, a larger SB with a stronger Shariah oversight capability would likely restrict the aggressive financing and lending activities of a manager, which could in effect minimize the risks of Islamic banks. From the viewpoint of stewardship theory, the board's size defines the board's ability to monitor and advise management. Coles, Daniel and Naveen (2008) indicated that in large and complex businesses, which are more diverse and require more professional guidance, a larger board size would be more effective.

The empirical evidence from a research on SB by Fakhrunnas and Ramly (2017) and the risk-taking conduct of Islamic Bank in South East Asia, which was observed over six cycles between 2009 and 2014, found that SB had a negative impact on it. A study by Almutairi and Quttainah in 2017 found that IBs with larger SB has increased in the organizational risk where the SB size coefficient is economically positive and significant, which means that one-unit increase in SB size is associated with an increase in bank risk of 0.4 per cents. Alman (2012) revealed that the risk-taking borrowing portfolio of Islamic banks is positively influenced by the rising size of the SB in 82 Islamic banks from 13 countries in the Middle East, North Africa and South East Asia. They concluded that the board size is correlated with issues of free-riding and longer decision-making durations. Safiullah and Shamsuddin (2018) found that an increase in the size of the SB would reduce the risk of insolvency of Islamic banks and create liquidity risk that is negligible.

\subsubsection{Shariah Board Education and Risk-Taking}

A relevant prior literature suggested that the capability of directors in board would increase through a high academic qualification for the purpose of interpretation and evaluation of information (Bantel, 1993), to join-part of complex problems with a variety of proposed solutions (Bantel \& Jackson, 1989) and to involve an in-depth assessment on implication on decision makings (Chen, 2014). Berger, Kick and Schaeck (2012) suggested that the cognitive abilities of the board of directors would increase their effectiveness in decision-making through the advanced academic qualifications (e.g. PhD degrees) and a strong guide monitoring of risk-taking behaviours.

With a suitable commitment package, a committed and trained boards, will protect the banking industry from overall credibility risks and through active supervision that is recognized which can evaluate Shariah compliance. Shariah boards' expertise and experience are the key element in judging and promoting Islamic banking Shariah compliant growth (SGF, 2010; IFSA, 2013). Without this growth, the risk can affect the shareholders short-term profits or benefits by inducing the board of directors to agree to compromise with Shariah principles. The involvement of Shariah literacy managers will prevent the primacy of profit motivation over compliance with Shariah. The licensing stage is particularly important from the regulatory point of view, whereby the licensing authority will request a clear demonstration of the commitment of sponsors to Islamic banking.

The members of the SB with advanced academic qualifications will improve their efficiency to formulate Islamic values in banking practices, including the introduction of an unreasonable moral risk prohibition (Ramly, Nurusysyifa \& Mohamad (2018). Suppose that, advanced academic qualifications may help SB members accurately assess the risk consequences of Shariah-compliant banking and provide guidelines for developing internal risk hedging techniques. Almutairi and Qutainnah (2017) argued that the probability of bank risk increased when the SB is highly educated. Conversely, Safiullah and Shamsuddin (2018) found that the percentage of SB members with advanced academic qualifications would lower the insolvency risk of Islamic banks.

\subsubsection{Shariah Board Membership and Risk-Taking}

Conflicts may arise from the Shariah context and understanding differences (i.e., Hanafi, Hanbali, Maliki, and Shafi'i), and these conflicts that promote different perceptions of Islamic bank inefficiency. The formation of the International Financial Services Board (IFSB) was therefore a step towards 
integration of the interpretations of Shariah law and religious rulings. In addition, the contradictory in fatwas will generate opposition and misinterpretation among the customers, employees, managers and directors of Islamic banks. Nevertheless, by implementing IFSB subscribers among Islamic banks, the fatwas can be consolidated, and these can boost banks' SB quality and soundness, as well as the organizational behavior and effectiveness.

The foundations of the Islamic Financial Institutions Accounting and Auditing Organization (AAOIFI) and IFSB will standardize the system of Islamic financial contracts and transactions and improve the systems of trade and governance. Empirical evidence from Almutairi and Qutainnah (2017) showed that SB is relevant with membership of IFSB and has a positive impact on bank risk. The emergence number of Islamic banks' individual SBs (approx. 80 percent of the total sample) is mostly members of at least one of those two global SBs that immediately liaise with these standard-setting Islamic organizations.

\subsubsection{Shariah Board Meeting and Risk-Taking}

Board meeting has significant relevant in corporate governance and the abnormal board meeting influenced the firm value (Vafeas, 1999). He further argued that the frequency of board meetings may be high due to the complexity and growth opportunities. Since Islamic banks involve in a variety of product transactions with Shariah law obligations, Muneeza and Hassan (2014) recommended that the SB should conduct meetings at least once a month and the attendance of all the SB members are made compulsory. These periodical meetings between SB, the board of directors and management board of banks may request consultations pertaining to Shariah issues. In Malaysia, the meetings of Shariah board shall be held in every two (2) months in every financial year. Each banks are also required to disclose the number of meetings attended by the SB scholars in the annual financial statement (BNM, 2009).

\subsubsection{Shariah Board Index}

Verriest, Ann and Daniel (2013) believed that the measurement of governance quality is more accurate by having aggregated indices than single indicators. Hence, in this manuscript, the measurement of Shariah governance characteristics and effectiveness using self-developed Shariah board index are aggregated by four (4) variables: SB size, SB level of education, SB IFSB membership and SB meeting frequency. The SB-Index is constructed based on Ajili and Bouri (2018), Mathew, Ibrahim, and Archbold (2017), SGF (2010) and IFSA (2013). Each variables included in the index are generated by giving the value of 1 when the value of the variable is either above or below the median and otherwise 0 .

Based on the argument above, the proposed hypothesis of this manuscript would state as follows:

\section{Hypothesis 1:}

Shariah board characteristics have significant negative relationship with risk-taking between the local and foreign Islamic banks in Malaysia.

\section{Hypothesis 2:}

Shariah board characteristics have significant negative relationship with insolvency risk between the local and foreign Islamic banks in Malaysia.

\section{Hypothesis 3:}

Shariah board characteristics have significant negative relationship with credit risk between the local and foreign Islamic banks in Malaysia.

\section{Hypothesis 4:}

Shariah board characteristics have significant negative relationship with liquidity risk between the local and foreign Islamic banks in Malaysia. 


\section{The Proposed Conceptual Model}

Figure 1 displays the proposed conceptual model of the research. This model is constructed from indepth prior literature research that concentrated on the characteristics of Shariah board including the number of scholars in Shariah board, percentage level of education who obtained $\mathrm{PhD}$ among the Shariah board, the scholars of IFSB member and the frequency of Shariah board meetings being held in every financial year ended. The self-developed of Shariah board index (SB-Index) was constructed from these four (4) Shariah board' attributes. The effect of Shariah board through SB-Index on risk-taking is tested by examining the aggregate of the risks: insolvency, credit and liquidity and individual risk.

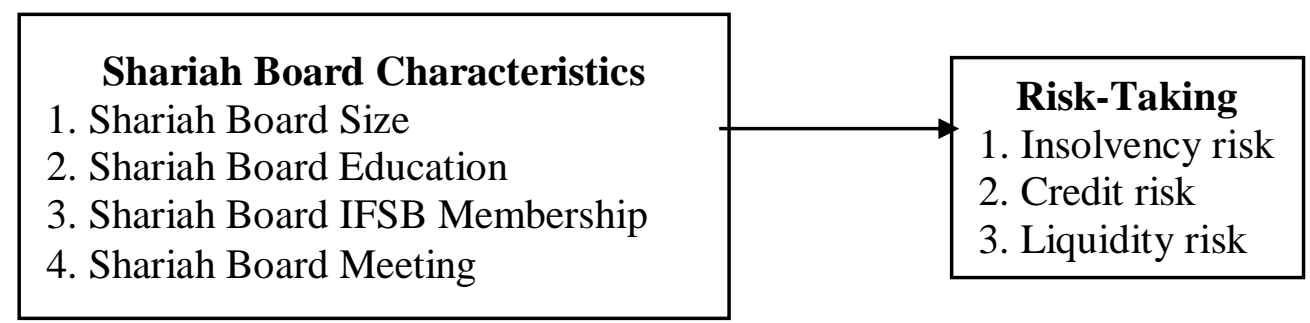

Figure 1: The proposed conceptual model on the effect of Shariah board characteristics on risk-taking of local and foreign Islamic banks in Malaysia.

\section{Potential Contributions and Conclusion}

The establishment of sound governance standards is often intentional to decrease the dynamic banking industries used in the unequal and risky financial products. Nevertheless, there are scant studies available to examine the impact of Shariah governance on Islamic banks' risk taking (Alman, 2012; Almutairi \& Qutainnah, 2017; Safiullah \& Shamsuddin, 2018). In addition, Mollah, Hassan, Al Farooque, and Mobarek (2017) indicated that similarities in Islamic banks and conventional banks' governance structure enabled both banks to take risks at a higher level in order to achieve better performance (Bhatti \& Bhatti, 2010). Therefore, the current research is an attempt to fill the gap in Shariah governance studies as many areas have not been discovered in such analysis, especially on the effect of high education of scholars and the frequency meetings of the Shariah board on risk-taking Islamic banks.

This manuscript has important policy consequences for the reform of the current advisory and supervisory system for regional banking regulators and the global regulatory standard-setting bodies of Islamic banks (e.g. AAOIFI, IFSB, and BNM). For example, if the central bank restructures the lending facilities of Islamic subsidiaries of conventional banks, Islamic banks will have a better position to mitigate their liquidity risk. In addition, customary limits on Islamic fixed income (sukuk) markets need to be levied by regulatory bodies.

The findings on the impact of the Shariah board's characteristics on Islamic banks 'risk-taking also have consequences for reforming and reconstructing the Islamic banks' governance structure. This 'additional layer' structure of bank governance with a broad Shariah board that is over-represented by highly educated scholars, technically acquired with qualified membership, and high frequency of Shariah board meetings will make bank risk reduction more successful.

\section{References}

Abdullah, H., \& Valentine, B. (2009). Fundamental and ethics theories of corporate governance. Middle Eastern Finance and Economics, 4(4).

Abedifar, P., Ebrahim, S. M., Molyneux, P., \& Tarazi, A. (2015). Islamic banking and finance: Recent empirical literature and directions for future research. Journal of Economic Surveys, 29(4), 637670. https://doi.org/10.1111/joes.12113

Abedifar, P., Molyneux, P., \& Tarazi, A. (2013). Risk in Islamic banking. Review of Finance, 17(6), 
2035-2096.

Ajili, H., \& Bouri, A. (2018). Corporate governance quality of Islamic banks: measurement and effect on financial performance. International Journal of Islamic and Middle Eastern Finance and Management, 11(3), 470-487. https://doi.org/10.1108/IMEFM-05-2017-0131

Alharthi, M. (2017). Financial performance and stability in Islamic banks: Evidence from GCC countries. Corporate Ownership \& Control, 14(4). https://doi.org/10.22495/cocv14i4art9

Alman, M. (2012). Shari'ah supervisory board composition effects on Islamic banks' risk-taking behavior. Journal of Banking and Regulation, 82(1), 1-43.

Ayunku, P. E. (2017). An Evaluation of liquidity management and banks performance in Nigeria: A correlation matrix approach. Noble International Journal of Business and Management Research, 1(8), 123-128.

Baele, L., Farooq, M., \& Ongena, S. (2014). Of religion and redemption: Evidence from default on Islamic loans. SSRN Electronic Journal.

Bank Negara Malaysia (BNM) (2013). Guidelines on corporate governance for licensed Islamic banks.

Bantel, K. A. (1993). Top team, environment, and performance effects on strategic planning formality. Group \& Organization Management, 18, 436-458. https://doi.org/10.1177/1059601193184004

Bantel, K. A., \& Jackson, S. E. (1989). Top management and innovations in banking: Does the composition of the top team make a difference? Strategic Management Journal, 10(1 S), 107-124. https://doi.org/10.1002/smj.4250100709

Basah, M. Y. A., Mohamad, S. N. A., Aziz, M. R. A., Khairi, K. F., Lalili, N. H., Sabri, H., \& Yusuf, M. M. (2018). Risks in Islamic banks: Challenges and management. Journal of Engineering and Applied Sciences, 13(8), 2081-2085.

Beck, T., Demirgüç-Kunt, A., \& Merrouche, O. (2013). Islamic vs. conventional banking: Business model, efficiency and stability. Journal of Banking and Finance, 37(2), 433-447. https://doi.org/10.1016/j.jbankfin.2012.09.016

Berger, A. N., Kick, T., \& Schaeck, K. (2012). Executive board composition and bank risk taking (Vol. 12). https://doi.org/10.1002/ir.37019906803

Bernadette Josephine, J., \& Corina, J. (2015). Corporate governance mechanisms and bank performance: Resource-based view. International Accounting and Business Conference 2015, 31(15), 117-123. https://doi.org/10.1016/S2212-5671(15)01138-7

Bhatti, M., \& Bhatti, I. (2009). Development in legal issues of corporate governance in Islamic finance. Journal of Economic \& Administrative Sciences, 25(1), 67-91.

Bilal Saeed, M., \& Kashif Saeed, S. (2018). Characteristics of shari'ah supervisory board, corporate governance mechanisms and efficiency of Islamic banks: Evidence from listed banks in Asia. Journal of Islamic Business and Management, 8(1), 116-138. https://doi.org/10.26501/jibm/2018.0801-008

Chakroun, M. A., \& Gallali, M. I. (2013). Islamic banks and financial stability: An empirical analysis of the Gulf countries. International Journal of Business and Commerce, 5(03), 64-87.

Chapra, M. U., \& Ahmed, H. (2002). Corporate governance in Islamic financial institutions.

Chen, H. L. (2014). Board capital, CEO power and R\&D investment in electronics firms. Corporate Governance: An International Review, 22(5), 422-436. https://doi.org/10.1111/corg.12076

Čihák, M., \& Hesse, H. (2010). Islamic banks and financial stability: An empirical analysis. In IMF Working Paper (No. 08). https://doi.org/10.1007/s10693-010-0089-0

Coles, J. L., Daniel, N. D., \& Naveen, L. (2008). Boards : Does one size fit all? Journal of Financial Economics, 87, 329-356. https://doi.org/10.1016/j.jfineco.2006.08.008

Cornforth, C., \& Chambers, N. (2010). The role of corporate governance and boards in organisational performance. In Connecting Knowledge and Performance in Public Services: From Knowing to Doing (pp. 99-127). https://doi.org/10.1017/CBO9780511762000.007

Dalton, D. R., Daily, C. M., Johnson, J. L., \& Ellstrand, A. E. (1999). Number of directors and financial performance: A meta-analysis. Academy of Management Journal, 42(6), 674-686. https://doi.org/10.2307/256988

Donaldson, L., \& Davis, J. H. (1991). Stewardship theory or agency theory: CEO governance and 
shareholder returns. Australian Journal of Management, 16(1), 49-64. https://doi.org/10.1177/031289629101600103

El-Hawary, D., Grais, W., \& Iqbal, Z. (2007). Diversity in the regulation of Islamic financial institutions. Quarterly Review of Economics and Finance, 46(5), 778-800. https://doi.org/10.1016/j.qref.2006.08.010

Errico, L., \& Farahbaksh, M. (1998). Islamic banking: Issues in prudential regulations and supervision (No. WP/98/30).

Faccio, M., Marchica, M. T., \& Mura, R. (2011). Large shareholder diversification and corporate risktaking. Review of Financial Studies, 24(11), 3601-3641. https://doi.org/10.1093/rfs/hhr065

Fakhrunnas, F., \& Ramly, Z. (2017). Board of directors and risk-taking behavior of Islamic banks in South East Asia. Tazkia Islamic Finance and Business Review, 10.2(September).

Grassa, R. (2013). Shariah supervisory system in Islamic financial institutions: New issues and challenges: A comparative analysis between Southeast Asia models and GCC models. Humanomics, 29(4), 333-348. https://doi.org/10.1108/H-01-2013-0001

Grassa, R., \& Matoussi, H. (2014). Corporate governance of Islamic banks: A comparative study between GCC and Southeast Asia countries. International Journal of Islamic and Middle Eastern Finance and Management, 7(3), 346-362. https://doi.org/10.1108/IMEFM-01-2013-0001

Hakimi, A., Rachdi, H., Mokni, R. B. S., \& Hssini, H. (2015). Do board characteristics affect bank performance? Evidence from the Bahrain Islamic banks. Journal of Islamic Accounting and Business Research, 30, 645-658. https://doi.org/http://dx.doi.org/10.1108/02683940010305270

Hasan, Z. (2010). Regulatory framework of Shar'iah governance system in Malaysia, GCC Countries and the UK. Kyoto Bulletin of Islamic Area Studies, 3-2(March), 82-115. https://doi.org/10.1108/17538391111122195

Hassan, M. K., \& Mollah, S. (2014). Corporate governance, risk-taking and firm performance of Islamic banks during global financial crisis. Finance and Development in Islamic Economies Conference, $1-36$.

Hillman, A. J., Cannella, A. A., \& Paetzold, R. L. (2000). The resource dependence role of corporate directors: Strategic adaptation of board composition in response to environmental change. Journal of Management Studies, 37(2), 235-256. https://doi.org/10.1111/1467-6486.00179

Htay, S. N. N., Rashid, H. M. A., Mohamad, A. A., \& Meera, A. K. M. (2012). Impact of corporate Governance on social and environmental information disclosure of Malaysian listed banks : Panel data analysis. Asian Journal of Finance \& Accounting, 4(1), 1-24. https://doi.org/10.5296/ajfa.v4i1.810

Ibrahim, H., Xiang, N. Y., Nik Azman, N. H., \& Zulkafli, A. H. (2018). Comparative study on board structure and performance between domestic and foreign banks in Malaysia. Economics, Management and Sustainability, 3(2), 42-59. https://doi.org/10.14254/jems.2018.3-2.4

Islamic Financial Services Act (IFSA) 2013, Law of Malaysia, Bank Negara Malaysia

Ismail, M. I. B. I., \& Hassan, R. B. (2016). Shari'ah committee composition in Malaysian Islamic inancial institutions: Post implementation of SGF 2010 and IFSA 2013. Journal of Islamic Finance, 5(2), 28-36. https://doi.org/10.12816/0045115

Ismal, R. (2010). Strengthening and improving the liquidity management in Islamic banking. Humanomics, 26(1), 18-35. https://doi.org/10.1108/08288661011024977

Laeven, L., \& Levine, R. (2007). Corporate governance, regulation, and bank risk taking. In World Bank Working Paper.

Lindgren, C., Garcia J. G., \& Saal, I. (1996). Bank soundness and macroeconomic policy, International Monetary Fund, Washington, D.C.

Masruki, R., Mohd Hanefah, M., \& Ab. Wahab, N. (2018). Shariah supervisory board (SSB) and performance of Islamic banks in Malaysia. International Journal of Engineering \& Technology, 7, 710-714. Retrieved from https://journal.wahedinvest.com/shariah-supervisory-board-ssb-the-dnaof-islamic-banks/

Mathew, S., Ibrahim, S., \& Archbold, S. (2017). Corporate governance and firm risk. Corporate Governance, 18(1), 52-67. https://doi.org/10.1108/CG-02-2017-0024 
Mirza, N., Rahat, B., \& Reddy, K. (2016). Financial leverage and stock returns: Evidence from an emerging economy. Economic Research-Ekonomska Istrazivanja , 29(1), 85-100. https://doi.org/10.1080/1331677X.2016.1160792

Misman, F. N., Bhatti, I., Lou, W., Samsudin, S., \& Abd Rahman, N. H. (2015). Islamic banks credit fisk: A panel study. Procedia Economics and Finance, 31(15), 75-82. https://doi.org/10.1016/s2212-5671(15)01133-8

Mokni, R. B. S., Rajhi, M. T., \& Rachdi, H. (2016). Bank risk-taking in the MENA region: A comparison between Islamic banks and conventional banks. International Journal of Social Economics, 43(12), 1367-1385. https://doi.org/10.1108/IJSE-03-2015-0050

Mollah, S., Hassan, M. K., Al Farooque, O., \& Mobarek, A. (2017). The governance, risk-taking, and performance of Islamic banks. Journal of Financial Services Research, 51(2), 195-219. https://doi.org/10.1007/s10693-016-0245-2

Mollah, S., \& Zaman, M. (2015). Shari'ah supervision, corporate governance and performance: Conventional vs . Islamic banks. Journal of Banking and Finance, 1-39.

Muchhala, B. (2007). Ten years after: Revisiting the Asian financial crisis. In Woodrow Wilson International Center for Scholars. Retrieved from http://www.sciencemag.org/content/313/5786/484.2.short\%5Cnhttp://scholar.google.com/scholar?h $\mathrm{l}=$ en\&btnG=Search\&q=intitle:Ten+years+after:+Revisiting+the+Asian+Financial+Crisis\#0

Muda, M., Shaharuddin, A., \& Embaya, A. (2013). Comparative analysis of profitability determinants of domestic and foreign Islamic banks in Malaysia. International Journal of Economics and Financial Issues, 3(3), 559-569.

Muneeza, A., \& Hassan, R. (2014). Shari'ah corporate governance: The need for a special governance code. Corporate Governance: The International Journal of Business in Society, 14(1), 120-129. https://doi.org/10.1108/CG-02-2011-0015

Nomran, N. M., Haron, R., \& Hassan, R. (2017). Bank performance and Shari'ah supervisory board bttributes by Islamic banks: Does bank size matter? Journal of Islamic Finance IIUM, 6(Special Issue), 174-186.

Nomran, N. M., Haron, R., \& Hassan, R. (2018). Shari'ah supervisory board characteristics effects on Islamic banks' performance: Evidence from Malaysia. International Journal of Bank Marketing, 36(2), 290-304.

Olagunju, A., David, A. O., \& Samuel, O. O. (2011). Liquidity management and commercial banks' profitability in Nigeria. Research Journal of Finance and Accounting, 28(7), 24-39.

Othman, A. A., Hassan, R., Omar, M. N., Napiah, M. D. M., Ariffin, M., Yusoff, A., ... Zaharim, A. (2013). Shariah Governance for Islamic Financial Institutions in Malaysia on the Independency of Shariah Committee and Efficiency of Its Shariah Decisions. Recent Advances in Management, Marketing and Finances, 93-100.

Paligorova, T. (2011). Corporate risk-taking and ownership structure. In SSRN Electronic Journal. https://doi.org/10.2139/ssrn.1364393

Ramly, Z., Nurusysyifa, \& Mohamad. (2018). Sharia supervision board, board independence, risk committee and risk-taking of Islamic banks in Malaysia. International Journal of Economics and Financial Issues, 8(4), 290-300.

Safiullah, M., \& Shamsuddin, A. (2018). Risk in Islamic banking and corporate governance. Pacific Basin Finance Journal, 47(December), 129-149. https://doi.org/10.1016/j.pacfin.2017.12.008

Sulaim, U., \& Rashid, A. (2018). The regulatory framework on liquidity risk management of Islamic banking in Malaysia. International Journal of Business and Society, 19, 332-352.

Shariah Governance Framework (SGF) for Islamic Financial Institutions. (2009). Bank Negara Malaysia, 22(i), 1-48. https://doi.org/10.1007/s13398-014-0173-7.2.

Vafeas, N. (1999). Board meeting frequency and firm performance. Journal of Financial Economics, 53(1), 113-142. https://doi.org/10.1016/S0304-405X(99)00018-5

Verriest, A., Ann G., \& Daniel B. T. (2013). The impact of corporate governance on IFRS adoption choices. European Accounting Review, 22(1), 39-77. 